\title{
QUANTITATIVE STUDIES ON THE DISPERSAL OF SKIN BACTERIA INTO THE AIR
}

\author{
W. C. Noble*, J. D. F. Habbema $\dagger$, R. van Furth $\ddagger$, \\ INGRID SMITH§ AND CARLA DE RAAY§ \\ * Department of Bacteriology, St John's Hospital for Diseases of the Skin, Homerton Grove, \\ London E9 6BX; † Department of Medical Statistics, University of Leiden; $\ddagger$ Depart- \\ ment of Microbial Diseases and Hospital Epidemiology Unit; and § Hospital Epidem- \\ iology Unit, University Hospital, Leiden, The Netherlands
}

DISPERSAL of micro-organisms from the body surface into the air occurs mainly on particles of desquamated skin. Some people appear to have a special ability to disseminate their pathogenic flora in this way and have been termed " dispersers". There are, however, some curious observations relating to such dispersal; males disperse more than females, healthy young males are significantly more often dispersers of Staphylococcus aureus than are females, and dissemination of all organisms appears to be greater from below the waist than from above it (Hill, Howell and Blowers, 1974; Mitchell and Gamble, 1974).

There is no agreed definition of a disperser; Noble (1962) described as dispersers of $S$. aureus persons who disseminated this organism as more than $1 \%$ of the total disseminated flora whilst undressing. According to Blowers a disperser was a person who disseminated more than 10 particles bearing this organism into a room of volume $100 \mathrm{cu} . \mathrm{ft}\left(2.83 \mathrm{~m}^{3}\right)$ during exercise (Bethune et al., 1965). In practice the two definitions are surprisingly close. It is clear from the work of Solberg, however, that there is a complete spectrum of dispersal and that any chosen cut-off for a specific organism is arbitrary (Solberg, 1965; Solberg, Bruun and Bøe, 1972). In defining as dispersers those who disseminate a potentially pathogenic micro-organism, it is easy to lose sight of the fact that all persons are dispersers or disseminators of their own normal flora. Any organism appearing on the skin will be dispersed as a result of normal desquamation.

There do not appear to have been any systematic studies of dispersal in relation to quantitative assessment of the normal skin flora. This paper reports such a study and seeks to explore the origin of dispersed organisms.

\section{METHODS}

The volunteers investigated were members of surgical or nursing teams ( 38 males and 34 females), each of whom was examined once only. They were asked to undress completely

Received 19 May 1975; accepted 3 July 1975.

Requests for reprints should be sent to W.C.N.

J. MED. MICROBIOL.-VOL. 9 (1976) 
in a chamber $(0.90 \mathrm{~m} \times 1.15 \mathrm{~m} \times 2.35 \mathrm{~m})$ whilst a slit sampler was running. The sampler ran for $2 \mathrm{~min}$. and sampled 175 litres of air per min. on to a serum-agar plate (Oxoid Blood Agar Base, CM55, containing horse serum $5 \% \mathrm{v} / \mathrm{v}$ ). After this, the skin of participants was sampled bacteriologically by three methods. Contact-plate and scrub counts were made on the chest (anterior surface), back, mid-thigh, shin, forearm and abdomen; a contact plate only was used to sample the hair, and moistened alginate swabs were used to sample the anterior nares, axilla and perineum. For a detailed discussion of sampling methods see Noble and Somerville (1974).

Contact plates were made by overfilling the lid of a $5-\mathrm{cm}$ petri dish with serum agar (as above) so that the meniscus rose above the level of the plate. Contact plates were housed in larger petri dishes before use and during incubation. The surface area of medium in such a plate was $25 \mathrm{~cm}^{2}$.

Scrub counts (Williamson, 1956) were made by placing a Teflon cylinder on the skin, adding $5 \mathrm{ml}$ of elution fluid (Oxoid Nutrient Broth, CM1, with the addition of Tween 80, $0.1 \% \mathrm{v} / \mathrm{v}, p \mathrm{H} \mathrm{7.4}$ ), and scrubbing for $1 \mathrm{~min}$. with a Teflon rod. The area of skin sampled was $4 \mathrm{~cm}^{2}$.

Alginate swabs (soluble calcium alginate) were moistened with nutrient broth (Oxoid Nutrient Broth); after swabbing, they were dissolved in $5 \mathrm{ml}$ of citrate-hexametaphosphate buffer (trisodium citrate $0.5 \% \mathrm{w} / \mathrm{v}$ and sodium hexametaphosphate $0.5 \% \mathrm{w} / \mathrm{v}$ ).

Fluids obtained by the scrub and the swab method were diluted in 10-fold steps; the diluent was 9 volumes of physiological saline containing Tween $800.05 \%(v / v)$ and 1 volume of nutrient broth. Five drops, each of $0.025 \mathrm{ml}$, were inoculated on to a plate of serum agar and a plate of blood agar (Oxoid Blood Agar Base with the addition of horse blood $7 \% \mathrm{v} / \mathrm{v}$ ).

After the plates had been incubated aerobically for 2 days at $37^{\circ} \mathrm{C}$, counts were made of the total number of colonies. Colonies of Micrococcaceae and diphtheroids were recognised visually and counted separately, cellular morphology being checked when necessary by the examination of preparations negatively stained with nigrosin. Colonies of potentially pathogenic micro-organisms, when present, were also recognised visually and counted separately. " Potential pathogens" were considered to include $S$. aureus, $\beta$-haemolytic streptococci, enterococci, and all aerobic gram-negative bacilli; whenever possible, these organisms were identified by conventional methods (Cowan and Steel, 1965).

For analysis, all results were converted to logarithms, because counts of skin bacteria at a given site in a population appear to conform closely to a log normal distribution (Noble and Somerville, 1974). The contact plate is assumed to measure the number of microcolonies at the skin surface, and the scrub count to measure the total number of viable cells present. The ratio $\frac{\text { scrub count per } \mathrm{cm}^{2}}{\text { contact count per } \mathrm{cm}^{2}}$ gives a measure of the size of the microcolonies at the skin surface. The alginate swab yields a semi-quantitative count which lacks the precision of the scrub count but is a fair reflexion of the flora at the site sampled (Noble and Somerville, 1974). Since the air sampler measures a constant volume of the air of the chamber, the plate count from the sampler was used as a direct estimate of dispersal.

\section{RESULTS}

\section{Dispersal of potential pathogens}

Dispersal of potential pathogens was infrequent (table I); only five of the 72 persons could be said to have dispersed such an organism significantly (airsampler plate count $>3$ colonies) under our experimental conditions, and another two dispersed smaller numbers of organisms. The gram-negative rods isolated did not include any commonly recognised pathogens such as Proteus, Pseudomonas, Klebsiella, Citrobacter, Escherichia or Acinetobacter. In addition to the persons listed in table I, there were 30 others who, despite having a major source of a potential pathogen on the body surface, did not appear to disperse 
TABLE I

Dispersal of potential pathogens*, and other micro-organisms, into the air by seven volunteers $\dagger$

\begin{tabular}{|c|c|c|c|c|c|c|}
\hline \multirow{2}{*}{$\begin{array}{l}\text { Volunteer } \\
\text { number }\end{array}$} & \multirow{2}{*}{ Sex } & \multirow{2}{*}{$\begin{array}{l}\text { Potential pathogen } \\
\text { dispersed }\end{array}$} & \multicolumn{2}{|c|}{$\begin{array}{l}\text { Number of colonies } \\
\text { dispersed into the air }\end{array}$} & \multicolumn{2}{|c|}{$\begin{array}{l}\text { Presumed source of the } \\
\text { potential pathogen }\end{array}$} \\
\hline & & & $\begin{array}{l}\text { Potential } \\
\text { pathogen }\end{array}$ & $\begin{array}{l}\text { Any micro- } \\
\text { organism }\end{array}$ & Major£ & Minor§ \\
\hline $\begin{array}{l}1 \\
2 \\
3\end{array}$ & $\begin{array}{l}\mathbf{M} \\
\mathbf{M} \\
\mathbf{F}\end{array}$ & $\begin{array}{l}\text { Gram-negative rod } \\
\text { Gram-negative rod } \\
\text { Group-B haemolytic } \\
\text { streptococcus }\end{array}$ & $\begin{array}{r}360 \\
120 \\
40\end{array}$ & $\begin{array}{r}3685 \\
3380 \\
865\end{array}$ & $\begin{array}{l}\text { Arm, hair } \\
\text { Perineum }\end{array}$ & $\begin{array}{l}\cdots \\
\cdots \\
\cdots\end{array}$ \\
\hline $\begin{array}{l}4 \\
5 \\
2\end{array}$ & $\begin{array}{l}\mathbf{M} \\
\mathbf{F} \\
\mathbf{M}\end{array}$ & $\begin{array}{l}\text { Enterococcus } \\
\text { Gram-negative rod } \\
\text { Staphylococcus aureus }\end{array}$ & $\begin{array}{r}20 \\
5 \\
4\end{array}$ & $\begin{array}{r}960 \\
293 \\
3380\end{array}$ & $\begin{array}{l}\text { Perineum } \\
\text { Leg } \\
\quad \ldots\end{array}$ & $\begin{array}{l}\text { Abdomen } \\
\text { Arm, chest } \\
\text { thigh, } \\
\text { abdomen. }\end{array}$ \\
\hline 6 & F & $\begin{array}{l}\text { Group-B haemolytic } \\
\text { streptococcus }\end{array}$ & 2 & 210 & Perineum & $\ldots$ \\
\hline 7 & $\mathbf{F}$ & S. aureus & 1 & 764 & Nose & $\cdots$ \\
\hline
\end{tabular}

* See text.

$\dagger$ Sixty-five volunteers did not disperse any potential pathogens. Note: one volunteer appears twice in the table.

$¥$ In 350 litres.

$\$$ Major source: a skin area from which more than 100 colonies of the organism were isolated by scrub count or alginate swab or more than 10 colonies on the contact plate. Minor source: an area from which smaller numbers of the organism were isolated.

that organism, though only in three instances were these major sources at sites other than the nose, axilla or perineum. A major source was defined as a site from which more than 100 colonies of the organism were isolated by scrub count or alginate swab, or more than 10 colonies on the contact plate.

\section{Dispersal of normal skin flora}

There was a highly significant difference between the total numbers of organisms dispersed by males and by females; mean dispersal for males was 2506 organisms per plate and for females $692(\mathrm{P}<0.01 \%)$. The $95 \%$ confidence limits show that, on average, males dispersed between 2.5 and 5 times as many viable bacteria-carrying particles as did females.

Table II shows that there were considerable differences between the counts from various body sites on males and females. With the exception of the nose, males had higher mean counts than females at all sites, though not all differences were statistically significant because of the wide scatter of counts in the groups under comparison. This finding is in general agreement with those of other quantitative studies (Noble and Somerville, 1974). When the greater density of colonisation of males was taken into account, however, it 
TABLE II

Total counts of organisms at various sites on the body surface of males and females

\begin{tabular}{|c|c|c|c|c|}
\hline \multirow{2}{*}{$\begin{array}{l}\text { Method of } \\
\text { sampling } \\
\text { (area sampled) }\end{array}$} & \multirow[b]{2}{*}{ Site } & \multicolumn{2}{|c|}{ Mean count* for } & \multirow{2}{*}{$\begin{array}{c}\text { Statistical } \\
\text { significance } \\
(t \text { test })\end{array}$} \\
\hline & & $\begin{array}{c}\text { males } \\
(n=38)\end{array}$ & $\begin{array}{c}\text { females } \\
(n=34)\end{array}$ & \\
\hline $\begin{array}{l}\text { Scrub count } \\
\qquad\left(4 \mathrm{~cm}^{2}\right)\end{array}$ & $\begin{array}{l}\text { Thigh } \\
\text { Abdomen } \\
\text { Shin } \\
\text { Arm } \\
\text { Chest } \\
\text { Back }\end{array}$ & $\begin{array}{r}10470 \\
2344 \\
2455 \\
549 \\
3890 \\
468\end{array}$ & $\begin{array}{r}1230 \\
646 \\
692 \\
389 \\
741 \\
309\end{array}$ & $\begin{array}{l}P<0.1 \% \\
P<1 \% \\
P<1 \% \\
N S \\
P<1 \% \\
N S\end{array}$ \\
\hline $\begin{array}{l}\text { Contact plate } \\
\left(25 \mathrm{~cm}^{2}\right)\end{array}$ & $\begin{array}{l}\text { Hair } \\
\text { Thigh } \\
\text { Shin } \\
\text { Arm } \\
\text { Chest } \\
\text { Abdomen } \\
\text { Back }\end{array}$ & $\begin{array}{r}324 \\
873 \\
549 \\
178 \\
263 \\
162 \\
55\end{array}$ & $\begin{array}{r}81 \\
220 \\
234 \\
109 \\
126 \\
107 \\
48\end{array}$ & $\begin{array}{l}\mathrm{P}<0.1 \% \\
\mathrm{P}<0.1 \% \\
\mathrm{P}<5 \% \\
\mathrm{NS} \\
\mathrm{P}<5 \% \\
\mathrm{NS} \\
\mathrm{NS}\end{array}$ \\
\hline $\begin{array}{l}\text { Alginate swab } \\
\text { (not defined) }\end{array}$ & $\begin{array}{l}\text { Axilla } \\
\text { Nose } \\
\text { Perineum }\end{array}$ & $\begin{array}{r}147900 \\
19500 \\
275400\end{array}$ & $\begin{array}{r}53700 \\
30200 \\
186200\end{array}$ & $\begin{array}{l}\text { NS } \\
\text { NS } \\
\text { NS }\end{array}$ \\
\hline
\end{tabular}

was apparent that the difference in dispersal between males and females was not significant (table III).

It was also clear that the correlation between amount of dispersal and density of the skin flora varied between body areas (table IV). The areas for which the colony count was most strongly correlated with dispersal were generally those below the waist line, though the individual area differed for males and females. In an attempt to determine whether any area could be identified as the " most important" in relation to dispersal, a forward stepwise regression analysis was performed; table $\mathrm{V}$ shows that different areas were identified in the two sexes.

Correlation coefficients between dispersal and the mean microcolony size were significant only for thigh $(\mathrm{r}=0 \cdot 26, \mathrm{P}<5 \%)$ and $\operatorname{shin}(\mathrm{r}=0 \cdot 28, \mathrm{P}<2 \%)$ when considered for all of the persons sampled.

The results for the two major components of the skin flora (Micrococcaceae and diphtheroids) showed the same tendency as those for the total flora (table VI). It must be recognised, however, that because the two groups of organisms were differently distributed in males and females, data for both sexes combined are difficult to interpret. Mean dispersal of diphtheroids was greater amongst males (mean: 1020 colonies) than among females (mean : 191 colonies) $(\mathrm{P}<0.1 \%)$. Similarly, males dispersed more Micrococcaceae (mean: 1190 colonies) than did females (mean: 366 colonies) $(\mathrm{P}<0.01 \%)$. Further 
TABLE III

Effect of sex on dispersal; analysis of mean errors in predicting the amount of dispersal from the total bacterial count of the skin flora

\begin{tabular}{|c|c|c|c|c|c|c|c|c|}
\hline \multirow{3}{*}{$\begin{array}{l}\text { Mean errors } \\
\text { computed from } \\
\text { data from }\end{array}$} & \multicolumn{8}{|c|}{ Ratios of the indicated mean errors in the prediction of the amount of dispersal from } \\
\hline & \multicolumn{2}{|c|}{ scrub counts on } & \multicolumn{2}{|c|}{$\begin{array}{l}\text { alginate-swab } \\
\text { counts on }\end{array}$} & \multicolumn{2}{|c|}{$\begin{array}{l}\text { contact-plate } \\
\text { counts on }\end{array}$} & \multicolumn{2}{|c|}{ all counts on } \\
\hline & males & females & males & females & males & females & males & females \\
\hline$\frac{\text { Other sex }}{\text { Own sex }}$ & $2 \cdot 3$ & $1 \cdot 7$ & $2 \cdot 6$ & $2 \cdot 0$ & $2 \cdot 4$ & $2 \cdot 3$ & $3 \cdot 9$ & $2 \cdot 6$ \\
\hline$\frac{\text { Total data }}{\text { Own sex }}$ & $1 \cdot 2$ & $1 \cdot 2$ & $1 \cdot 5$ & $1 \cdot 3$ & $1 \cdot 3$ & $1 \cdot 2$ & $1 \cdot 3$ & $1 \cdot 7$ \\
\hline
\end{tabular}

* Analysis was made by computing the mean error in predicting the amount of dispersal from counts of skin flora. The regression lines were computed from " own sex", "other sex" and " total data ". Mean errors should be least for the "own sex" data, and the closer the mean errors for "other sex" and "total data" approach " own sex" the less the effect of sex. The mean errors for the "total data " were very close to " own sex", suggesting that, when the effect of difference in colonisation was removed, there was little effect of sex on dispersal.'

subdivision of these results was not thought meaningful because individual subjects tended to have a predominantly coccal or diphtheroid flora, and this resulted in very low counts for the alternative group. Nil counts have been treated as if half a colony-forming unit was isolated. It was necessary to apply this correction only when the Micrococcaceae and diphtheroids were considered separately.

\section{Discussion}

The main medical interest in dispersal of micro-organisms lies in the possibility that a pathogen may be disseminated in great numbers to the detriment of patients or staff in a hospital (Noble, 1962; Ayliffe and Collins, 1967; Payne, 1967). None of the members of hospital surgical or nursing teams we examined appeared likely to be a hazard to patients, though large numbers of gramnegative rods (not identifiable as one of the more common potential pathogens) were liberated into the air while one of the volunteers undressed. Two other persons dispersed smaller numbers of similar gram-negative rods. Gramnegative bacilli have not apparently been reported as causing infection when dispersed in this way.

Nevertheless, " dispersal" has a strong intrinsic interest. It is now agreed that the majority of organisms disseminated during undressing are airborne on flakes of desquamated epithelium known as "skin scales " or "squames" (Davies and Noble, 1962), which are slightly larger in females than in males (Plewig, 1970). It is difficult to assess the effect of this on dispersal; but if Plewig's figures are applied to the whole body, males ought to disperse about 
TABLE IV

Correction between the total number of organisms dispersed and the total count at various body sites

\begin{tabular}{|c|c|c|c|}
\hline \multirow{2}{*}{ Site } & \multirow{2}{*}{$\begin{array}{l}\text { Method of } \\
\text { sampling }\end{array}$} & \multicolumn{2}{|c|}{$\begin{array}{l}\text { Correlation coefficient (and its } \\
\text { statistical significance) for }\end{array}$} \\
\hline & & males & females \\
\hline $\begin{array}{l}\text { Thigh } \\
\text { Abdomen } \\
\text { Arm } \\
\text { Shin } \\
\text { Chest } \\
\text { Back }\end{array}$ & $\begin{array}{l}\text { Scrub count } \\
\text { Scrub count } \\
\text { Scrub count } \\
\text { Scrub count } \\
\text { Scrub count } \\
\text { Scrub count }\end{array}$ & $\begin{array}{l}0.44(\mathrm{P}<1 \%) \\
0.45(\mathrm{P}<1 \%) \\
0.33(\mathrm{P}<5 \%) \\
0.18 \text { (NS) } \\
0.06 \text { (NS) } \\
0.00 \text { (NS) }\end{array}$ & $\begin{array}{l}0.30 \text { (NS) } \\
0.19 \text { (NS) } \\
0.12 \text { (NS) } \\
0.42(\mathrm{P}<1 \%) \\
-0.14 \text { (NS) } \\
-0.17 \text { (NS) }\end{array}$ \\
\hline $\begin{array}{l}\text { Thigh } \\
\text { Abdomen } \\
\text { Arm } \\
\text { Shin } \\
\text { Chest } \\
\text { Back } \\
\text { Hair }\end{array}$ & $\begin{array}{l}\text { Contact plate } \\
\text { Contact plate } \\
\text { Çontact plate } \\
\text { Contact plate } \\
\text { Contact plate } \\
\text { Contact plate } \\
\text { Contact plate }\end{array}$ & $\begin{array}{l}0.23(\mathrm{NS}) \\
0.45(\mathrm{P}<1 \%) \\
0.49(\mathrm{P}<1 \%) \\
0.25(\mathrm{NS}) \\
0.44(\mathrm{P}<1 \%) \\
0.08(\mathrm{NS}) \\
0.32(\mathrm{P}<5 \%)\end{array}$ & $\begin{array}{l}0.39(\mathrm{P}<5 \%) \\
0.21 \text { (NS) } \\
0.20 \text { (NS) } \\
0.49 \text { (P }<1 \%) \\
0.12 \text { (NS) } \\
0.30 \text { (NS) } \\
0.16 \text { (NS) }\end{array}$ \\
\hline $\begin{array}{l}\text { Axilla } \\
\text { Nose } \\
\text { Perineum }\end{array}$ & $\begin{array}{l}\text { Alginate swab } \\
\text { Alginate swab } \\
\text { Alginate swab }\end{array}$ & $\begin{array}{l}0.08 \text { (NS) } \\
0.07 \text { (NS) } \\
0.19 \text { (NS) }\end{array}$ & $\begin{array}{r}0.16 \text { (NS) } \\
0.29 \text { (NS) } \\
-0.07 \text { (NS) }\end{array}$ \\
\hline
\end{tabular}

1.25 times as many scales as females of the same surface area. In the persons investigated by Noble and Davies (1965), whose height and weight were known at the time of sampling, the males had a larger skin surface area than the females by 1.16 times. In general, therefore, males might be expected to disperse about 1.45 times as many scales as females. In Noble and Davies' (1965) series the male/female ratio for dispersal of scales by persons wearing identical hospital clothing was $1 \cdot 34$ and wearing street clothing $1 \cdot 80$. No other relevant studies of squames appear to have been reported.

It had been established previously that males disperse more organisms than do females. The nature of the clothing worn by members of the two sexes accounts for some of the difference, but a significant amount remains even when identical clothing is used (Noble and Davies, 1965; Speers et al., 1965; May and Pomeroy, 1973); this is presumably due to heavier colonisation of the skin surface in males than in females.

Workers who have concentrated on the dispersal of $S$. aureus have found that among healthy persons there are relatively few females amongst those who disseminate this organism (Ayliffe, Babb and Collins, 1973; Blowers, Hill and Howell, 1973; Hill et al., 1974; Mitchell and Gamble, 1974) though female dispersers have been identified in some studies, especially of surgical or dermatological patients (Solberg, 1965; Oud, 1969; Noble, 1971). Although nasal carriage of $S$. aureus may result in dispersal, perineal carriage seems more 
TABLE V

Skin-surface areas selected by a stepwise regression analysis as " most important" for dispersal

\begin{tabular}{cl|llc}
\hline \multirow{2}{*}{ Sex } & $\begin{array}{c}\text { Method of } \\
\text { sampling }\end{array}$ & \multicolumn{3}{|c}{ Area selected } \\
\hline \multirow{2}{*}{ Males } & $\begin{array}{l}\text { Scrub count } \\
\text { Contact count }\end{array}$ & $\begin{array}{l}\text { Abdomen } \\
\text { Frm }\end{array}$ & $\begin{array}{l}\text { Thigh } \\
\text { Chest }\end{array}$ & Hair \\
& $\begin{array}{l}\text { Scrub count } \\
\text { Contact count }\end{array}$ & $\begin{array}{l}\text { Shin } \\
\text { Shin }\end{array}$ & Back & $\ldots$ \\
& & $\ldots$ & $\ldots$ \\
\hline
\end{tabular}

TABLE VI

Correlation between the total number of organisms dispersed and (1) the total count and the count of (2) Micrococcaceae and (3) diphtheroids at various body sites; the results for males and females are combined

\begin{tabular}{|c|c|c|c|c|}
\hline \multirow{2}{*}{ Site } & \multirow{2}{*}{$\begin{array}{l}\text { Method of } \\
\text { sampling }\end{array}$} & \multicolumn{3}{|c|}{ Correlation coefficient (and its statistical significance) for } \\
\hline & & total aerobic flora & Micrococcaceae only & diphtheroids only \\
\hline $\begin{array}{l}\text { Thigh } \\
\text { Shin } \\
\text { Abdomen } \\
\text { Arm } \\
\text { Chest } \\
\text { Back }\end{array}$ & $\begin{array}{l}\text { Scrub count } \\
\text { Scrub count } \\
\text { Scrub count } \\
\text { Scrub count } \\
\text { Scrub count } \\
\text { Scrub count }\end{array}$ & $\begin{array}{l}0.57(\mathrm{P}<0.1 \%) \\
0.47(\mathrm{P}<0.1 \%) \\
0.46(\mathrm{P}<0.1 \%) \\
0.27(\mathrm{P}<5 \%) \\
0.17 \text { (NS) } \\
0.03 \text { (NS) }\end{array}$ & $\begin{array}{l}0.35 \text { (P<1\%) } \\
0.22 \text { (NS) } \\
0.29 \text { (P<2\%) } \\
0.03 \text { (NS) } \\
0.10 \text { (NS) } \\
-0.11 \text { (NS) }\end{array}$ & $\begin{array}{l}0.44(\mathrm{P}<0.1 \%) \\
0.30(\mathrm{P}<2 \%) \\
0.29(\mathrm{P}<2 \%) \\
0.24 \text { (NS) } \\
0.20 \text { (NS) } \\
0.20 \text { (NS) }\end{array}$ \\
\hline $\begin{array}{l}\text { Axilla } \\
\text { Perineum } \\
\text { Nose }\end{array}$ & $\begin{array}{l}\text { Alginate swab } \\
\text { Alginate swab } \\
\text { Alginate swab }\end{array}$ & $\begin{array}{l}0.23(\mathrm{P}=5 \%) \\
0.16(\mathrm{NS}) \\
0.01(\mathrm{NS})\end{array}$ & $\begin{array}{l}0.19 \text { (NS) } \\
0.13 \text { (NS) } \\
0.02 \text { (NS) }\end{array}$ & $\begin{array}{l}0.04 \text { (NS) } \\
0.17 \text { (NS) } \\
0.01 \text { (NS) }\end{array}$ \\
\hline
\end{tabular}

$\mathrm{NS}=$ not significant $(\mathrm{P}>5 \%)$

strongly related to it (Solberg, 1965); and it has been suggested that friction between the scrotum and thigh, sloughing off contaminated epithelial cells, may be responsible for the greater dispersal of $S$. aureus by males. than by females. Contamination of the skin surface is probably greater from perineal than from nasal carriage.

The present study shows however that the pattern of dispersal from the various body sites when undressing is different for males and females. In males, the skin count of normal flora on the thighs and abdomen is strongly correlated with dispersal whereas in females the shin may be more important, perhaps due to the "cheese-grater" effect of tights (Mitchell and Gamble, 1974). Transient carriage of $S$. aureus is more common on the thighs than on the shins (Noble and Somerville, 1974), and this is no doubt a reflexion of simple mechanical spread from the perineum. Therefore, a greater tendency 
of males to disperse from the thighs would lead to greater dispersal of $S$. aureus, even if colonisation of the host was the same in both sexes.

From this study, as from others, it is clear that males support the growth of higher populations of skin organisms than do females, and this, in itself is reflected in the levels of dispersal. It seems likely that the observed dispersal is further influenced by differences in clothing, because there was a significantly greater dispersal by female nursing staff who came from a hospital outside the main complex and who were wearing conventional street clothing than by those who came from internal units and were wearing a cotton uniform dress $(\mathrm{P}<5 \%)$.

In other studies (Hill et al., 1974; Mitchell and Gamble 1974) attention has been paid to the use of specially designed surgical suits made of close woven fabric which retains the skin scales on the inside of the suit. Such suits significantly reduce dispersal of skin micro-organisms and are of benefit especially where even the so-called " non-pathogens" can be hazardous, as in operations for total hip replacement (Charnley and Eftekhar, 1969). Our present studies add weight to the suggestion that special attention should be paid to the design and use of trouser suits for both male and female staff.

\section{SUMMARY}

Dispersal of skin micro-organisms into the air during undressing was studied in 72 members of surgical and nursing staff. Few pathogens were found to be dispersed. Males dispersed more normal skin organisms than did females. Males were also more heavily colonised than females, and sex differences in dispersal diminished when allowance was made for the denser colonisation of males. Dispersal was correlated most strongly with the counts on the thighs and abdomen in males but on the shins in females.

We are grateful to the members of the various nursing and surgical teams who took part. Mr M. H. Rebel, Sister G. A. M. Berbee and Mrs M. W. de Haan-Mittertrainer are thanked for their role in organising this investigation.

\section{REFERENCES}

AYliffe, G. A. J., BabB, J. R. AND Collins, B. J. (1973). Dispersal and skin carriage of staphylococci in healthy male and female subjects and patients with skin disease. In Airborne transmission and airborne infection, edited by J. F. P. Hers and K. C. Winkler, Utrecht, p. 435.

AylifFe, G. A. J. AND Collins, B. J. (1967). Wound infections from a disperser of an unusual strain of Staphylococcus aureus. J. clin. Path., 20, 195.

Bethune, D. W., Blowers, R., Parker, M. and Pask, E. A. (1965). Dispersal of Staphylococcus aureus by patients and surgical staff. Lancet, 1,480 .

Blowers, R., Hinl, J., AND Howell, A. (1973). Shedding of Staphylococcus aureus by human carriers. In Airborne transmission and airborne infection, edited by J. F. P. Hers and K. C. Winkler, Utrecht, p. 432.

Charnley, J. and Eftekhar, N. (1969). Penetration of gown material by organisms from the surgeon's body. Lancet, $1,172$. 
Cowan, S. T. ANd Steel, K. J. (1965). Manual for the identification of medical bacteria, London.

Davies, R. R. AND Noble, W. C. (1962). Dispersal of bacteria on desquamated skin. Lancet, 2, 1295.

Hill, J., Howell, A. AND Blowers, R. (1974). Effect of clothing on dispersal of Staphylococcus aureus by males and females. Lancet, 2,1131 .

MAY, K. R. AND Pomeroy, N. P. (1973). Bacterial dispersion from the body surface. In Airborne transmission and airborne infection, edited by J. F. P. Hers and K. C. Winkler, Utrecht, p. 426.

Mitchell, N. J. AND Gamble, D. R. (1974). Clothing design for operating room personnel. Lancet, $2,1133$.

Noble, W. C. (1962). The dispersal of staphylococci in hospital wards. J. clin. Path., $15,552$.

Noble, W. C. (1971). The contribution of individual patients to the spread of infection. Br.J. Derm., 85, 24.

Noble, W. C. ANd Davies, R. R. (1965). Studies on the dispersal of staphylococci. $J$. clin. Path., 18, 16.

Noble, W. C. and Somerville, D. A. (1974). Microbiology of human skin, London.

Oud, J. A. C. (1969). Het strooien van Staphylococcus aureus in het algemeen en op operatie kamers in het bijzonder. M.D. Thesis, University of Amsterdam.

PAYNE, R. W. (1967). Severe outbreak of surgical sepsis due to Staphylococcus aureus of unusual type and origin. Br. med. J., 4, 17.

Plewig, G. (1970). Regional differences in cell size in the human stratum corneum. II. Effects of sex and age. J. invest. Derm., 54, 19.

SOlBERG, C. O. (1965). A study of carriers of Staphylococcus aureus. Acta med. scand., 178, Suppl 1.

Solberg, C. O., Bruun, J. N. ANd Bøe, J. (1972). Aerial dissemination of Staphylococcus aureus by hospital patients: causes and prevention. Prevent, $1,43$.

Speers, R., Bernard, H., O'Grady, F. AND Shooter, R. A. (1965). Increased dispersal of skin bacteria into the air after shower bathing. Lancet, 1,478 .

Williamson, P. (1965). Quantitative estimation of cutaneous bacteria. In Skin bacteria and their role in infection, edited by H. I. Maibach and G. Hildick-Smith, New York, p. 3. 